\title{
La Moral en la Obra de Montalvo
}

Por medio de su vida Juan Montalvo mostró mejor que en ninguno de stus escritos cuáles eran los principios que él consideraba más altos, cuáles eran las ideas que él defendía, cuál era el modo de vida que él consideraba digno, cuáles eran los valores fundamentales para él.

Montalvo nació en Ambato, Ecuador, en el año 1832. Recibió su primera educación en un "tenducho" de su pueblo natal, donde "todo era de segunda categoría", según sus propias palabras. Se trasladó a Quito, donde estudió en el Colegio de San Fernando, en el Seminario de San Luis y más tarde en la Universidad. Ocupó un cargo político, fué a Francia como miembro de la Legación del Ecuador. Viajó por Europa. Volvió a la patria en 1860 y encontró una época de agitación política. El estado de cosas en su país determinó el curso de su vida y el carácter de su obra en el futuro. Comenzó su labor como "azote de tiranos" con una carta dirigida a García Moreno en 1860. Nunca se reconcilió con la política corrompida. Su alta opinión de la dignidad del hombre siempre le hizo intransigente para con los dictadores y para con los débiles moralmente.

Es inútil enumerar las ocasiones que Montalvo tuvo que huir de su país y las veces que fué desterrado, lo que hizo durante su destierro y durante sus breves estancias en el Ecuador. Buenos biógrafos ya se han ocupado de ello. Este esquema biográfico se presenta aquí solamente para dar una idea muy breve de lo que era Montalvo en el campo político, que para él también era el campo moral.

La mayor parte de la producción del autor es obra de polémica. Muchas de estas polémicas se prolongan; un artículo provoca una contestación y Montalvo contesta con un tercero, y así prosigue. Buena parte de su obra nơ tiene interés ahora porque trata de asun- 
tos que en sus tiempos eran importantes, pero que hoy ya no nos despiertan curiosidad: cuestiones de politiquillos de aldea, ataques personales, acttsaciones de baja moral contra personas que ya èstán olvidadas ...

Hay que tener en cuenta la situación politica del país para poder comprender y apreciar la obra de Montalvo, y es más importante aún conocer al clera del Ecuador y su relación con el gobierno civil.

La situación política de aquella nación durante la vida de Montalvo puede resumirse en dos palabras: anarquía y dictadura. Anarquía seguida por una dictadura y dictadura que cae y se convierte en anarquía. Gobierno liberal depuesto por un García Moreno que permanece en el poder. Luchas con las repúblicas vecinas, intervenciones armadas para proteger a un partido o a otro. $\mathrm{Y}$ siempre $10 \mathrm{~s}$ clérigos apoyando a los conservadores, declarándose contra las reformas liberales, clamando por más y más derechos y privilegios. El fanatismo de los gobernantes, la corrupción de las costumbres, la superstición y la ignorancia del pueblo - tal era el panorama político y social en medio del cual vivió Montalvo.

Las aspiraciones de éste se hallan resumidas en el párrafo siguiente, en el cual contesta a las acusaciones lanzadas contra él:

\footnotetext{
... Yo pienso que cuarteles son para soldados, colegios para estudiantes... Quiero escuelas para los niños, planteles de educación para los jóvenes, universidades para los doctores... Deseo hospitales para los enfermos, casas de misericordia para los desamparados... Trabajo para la propagación de las virtudes, persigo los vicios, me estrello contra los crímenes... Vierto lágrimas por las miserias humanas, las ridiculeces de los hombres me causan risa, sus necedades me enfadan, sus maldades me enfurecen... Anhelo por la paz y el orden en medio de luces. la paz y el'orden en medio de la libertad... Mi gobierno, el gobierno de mis simpatías, es el ilustrado, el justo, el digno, el protector, el paternal, clero sabio, virtuoso, milicia pundonorosa... La ley primero que mi roluntad, el bien de todos antes que el mío... Destierro y no cadenas, hambres y no pan negro, soledad y no comunión con los perversos...1 1
}

Sus fuentes de inspiración y de ideas son "los selectos libros que no dejo de leer, y que me aprovechan tanto más cuanto que mi humilde inteligencia y mi corazón en ninguna manera se oponen a lo que encuentro bueno y grande en mis lecturas". ${ }^{2}$ 
Y Montalvo siempre tiene una fe profunda en sus convicciones:

No me gusta dar un paso fuera de mis deberes ni salir un punto de los límites de la justicia. 3

Montalvo había sido acusado de hereje, de impio, de masón sin fundamento alguno. Sus puntos de vista sobre la religión a veces diferian de los que mantenía el clero del Ecuador, pero para ello había varias razones.

En aquella época, cuando los conservadores se aliaban con la Iglesia contra los liberales, cualquiera que fuese la fe de éstos se les tachaba de impíos, ya que al atacar al partido contrario atacaban también al clero. Montalvo, como veremos más adelante, se expresó muchas veces como creyente ardoroso y sincero, enemigo de los materialistas, de los panteístas, de librepensadores en materia religiosa. Nunca negó la necesidad de la existencia del clero. Las diferencias entre su opinión y la de los miembros de aquél, en cuestiones de religión, eran de forma más que de fondo, y si tales discrepancias adquirieron una importancia tan grande fué porque en aquella época, cuando las ideas de los ultramontanos y de la sumisión completa a la potestad del Papa prevalecían entre los clérigos y los conservadores, el punto de vista de Montalvo resultaba demasiado radical.

Un breve estudio sobre el clero del Ecuador durante la época colonial y durante la vida de nuestro autor, nos explicará por qué él odiaba tanto a los religiosos de su país y por qué al referirse a ellos dijo:

No soy enemigo del cléro: los fanáticos me infunden miedo; los ignorantes lástima, los perversos odio, los corrompidos desprecio. ${ }^{4}$

En las Noticias secretas de América, por Juan y Ulloa, hay su. ficiente material para ver qué clase de sacerdotes tenía el Ecuador colonial. Los autores de las Noticias hablan de la licencia de las costumbres en general y de la de los religiosos en particular. Se refieren a la conducta en los conventos, que "lleva el ánimo a horror". 5 Aluden a los religiosos y los sacerdotes que viven en sus propias casas, tienen concubinas, "no disimulan su incontinencia". ${ }^{6}$

Tales condiciones del clero ni siquiera son negadas por miembros de la Iglesia Católica hoy en día. Las justificaciones que se dan 
para un estado semejante son varias: en primer lugar echan la culpa al patronato, y en segundo, consideran que las colonias sirvieron de lugar de destierro a los clérigos "malos" de España durante la época colonial :

All during the colonial period, the government at home continued the pernicious practice of using the colonies as dumping ground for priests who had given trouble in Spain. 7

Dicha razón $\mathrm{u}$ otra motivaron el estado de los eclesiásticos en el Ecuador y he aqui el resumen que hacen los autores de las Noticias, horrorizados de tener que contar estas cosas al rey, pero considerándolo su deber:

... así se ve que entre los vicios que hay en las Indias los de los religiosos sobresalen entre las otras clases de gentes, porque si en el uso de las mujeres, ningunos lo tienen más comúnmente, ni con más desenfado y desahogo que ellos; si es en el hablar causa horror el oírlos cuando se les desatan las lenguas y se vuelven instrumentos de mayor torpeza y sensualidad; ellos juegan más que ningunos otros, beben con más desorden... y no hay vicio que les sea ajeno...8

Durante la época de Montalvo, es decir, durante los principios de la república, el clero aspiraba al derecho de nombramiento. Las nuevas repúblicas querían el patronato, antiguamente en manos del rey de España. Montalvo siempre abogó por el patronato, y como es natural, tal actitud también lo marcó como un enemigo del clero. Atacó los puntos de colaboración fijados por el Concordato celebrado entre la Iglesia y el Estado del Ecuador en 1863. Este Concordato consistía en lo siguiente:

1 - El Catolicismo será la única religión del Ecuador.

2 - Ninguna religión o sociedad condenada por la Iglesia existirá en el Ecuador.

3 - El derecho del Patronato queda abolido, y en su lugar el Presidente elegirá entre tres nombres que se le presenten, cuando haya que nombrar un obispo.

4 - Los obispos tendrán la exclusiva supervisión de la enseñanza y las materias que se enseñen tendrán que estar en armonía con la doctrina cristiana. 
5 - Los obispos tendrán el derecho de prohibir libros opuestos a la religión o a la moral.

6 - E1 clero estará sujeto solamente a los tribunales eclesiásticos, y no habrá apelación a tribunales civiles.

Tales eran las condiciones del clero del Ecuador cuando Montalvo escribió sus obras. Es fácil comprender por qué él atacaba con tanta violencia al clero corrompido, digno sucesor del que se enviaba a las colonias por castigo, por qué deseaba libertad de expresión, por qué atacaba con tanto vigor a los eclesiásticos que usaban su poder para fines políticos.

En la obra de Montalvo existe una multitud de contradicciones, ya que se presenta a sí mismo como una mezcla de católico ortodoxo y librepensador. En un lugar ataca a los impios, y en otro él mismo parece tener creencias diferentes de las de la Iglesia. De esta masa de contradicciones, sin embargo, se pueden recoger varias conclusiones definitivas acerca de sus opiniones morales y religiosas.

\section{Las ideas religiosas de Montalvo}

$\mathrm{Al}$ analizar sus escritos es fácil llegar a la conclusión de que las ideas religiosas de Montalvo más bien parecen las de un "cristiano primitivo" que las de un librepensador; sus puntos de vista concuerdan en sus puntos esenciales con el Evangelio, aunque discrepan con ciertas reglas señaladas por el Concilio de Trento. Basta ver algunas citas donde habla de su concepto de Dios:

Comprender a Dios por la inteligencia sería igualarnos a él, superior es a nuestra comprensión, y si a ella hubiéramos de quedarnos, el Dios que comprendiésemos sería poco diferente de nosotros. 9

... no alcanzamos a conocer a Dios, pero estamos convencidos de que existe. 10

$Y$ esta seguridad de la existencia de Dios, sin conocerlo y sin comprenderlo, señala a Montalvo como un deísta, de acuerdo con la definición dada por la Enciclopedia Católica (tomo vi, p. 609). 
Como todo buen católico, Montalvo no duda de la inmortalidad del alma:

Tengamos por cierto que el Criador sopló sobre el hombre y le infundió su esencia, y le crió para la inmortalidad. 11

Tampoco muestra incredulidad ni vacilación al hablar del dogma de la Trinidad y de su misterio. (Véase El Cosmopolita, tomo II, p. 344.)

Pero Montalvo no sólo expresa su fe en Dios y en los dogmas fundamentales de la religión católica, sino que también ataca a los librepensadores, a los ateos, a los que no creen en los misterios de la religión y a quienes rechazan la idea de la existencia de Dios o la inmortalidad del alma. Un buen ejemplo de ello es su descripción de la entrevista que tuvo con Proudhon, donde razona para probar su punto de vista esencialmente ortodoxo y cuya esencia se halla en la demostración de que es una temeridad tratar de comprender a Dios. (Véase El Cosmopolita, tomo I, p. 254.) En esta discusión el autor se basa en la aceptación de los atributos de Dios. En el fondo de todas sus razones para demostrar que Dios existe se encuentra la premisa de que Dios existe; en sus razones para demostrar que Dios es único y solo, Montalvo se basa solamente en las premisas de que los atributos de Dios son el hecho de ser único y solo. $Y$ nuestro autor se indigna ante la osadía del filósofo francés que niega la existencia de Dios. Es interesante notar el lenguaje que usa Montalvo al hablar del "impío":

La razón ni la conciencia no han sido diques a la riada de presunción de aquel filósofo. Dotóle la naturaleza de talento sin par, y desdeñando nivelarse con los otros mortales, lanza bandera contra el Todopoderoso. Aliado del demonio, declara guerra al cielo, nada pone sueltas al disparo de su avilantez. ${ }^{12}$

Humildad ante Dios, práctica de las virtudes cristianas, son ideas que Montalvo no se cansa de presentar al lector. Sería interminable dar todos los ejemplos que se encuentran en stus obras. Basten unas cuantas citas:

En presencia de Dios... la humana sabiduría no es sino locura: y lo que en Dios parece incuerdo es más cuerdo que toda la sabiduría de los hombres, y lo que en Dios parece flaco, es más fuerte que toda la fuerza de los hombres. 13 
Amor de Dios es afección compuesta de todas las afecciones puras, amor de Dios es conjunto de virtudes y bellezas... el amor de Dios es amor a la verdad, amor a la virtud, amor al prójimo, amor a la naturaleza. 14

Las virtudes son todas hijas del amor de Dios y este amor comunica fuerzas superiores a la naturaleza humana, 15

Examinemos ahora las afirmaciones de Montalvo que molestaban al clero, sus ideas "revolucionarias" que habían ganado para él el nombre de hereje, ya que parece muy extraño que se haya tachado de impío a un hombre que había dicho:

Jesucristo hombre es un grande hombre, el mayor de todos. Jesucristo Dios es el que mantiene en el mundo la virtud $y$ tíra la rienda al crimen. La ley de Jesucristo debe ser no solamente ley religiosa, mas antes ley política: ${ }^{16}$

Una de las razones por las cuales se acusó a Montalvo de hereje, fué la de haber dicho que ciertos filósofos griegos y romanos fueron modelos de virtud. Es interesante ver el vigor con que Montalvo. responde a estas acusaciones estúpidas, siempre dentro de su condición de fiel cristiano y buen católico:

Mis ideas se hubieran desenvuelto a gusto de los más aprensivos cristianos, porque de las virtudes antiguas y modernas habría procurado destilar, si sufre decirse, una sola buena y verdadera. Todo lo que Jesucristo predicó después, Sócrates lo predicó antes; casi todo lo que Sócrates predicó antes, Jesucristo lo enseñó después... Sí, Sócrates es uno como profeta, en cierto modo precursor del Mesías. ${ }^{17}$

La virtud es virtud en todo tiempo y lugar... El Señor es magnánimo, el Señor es generoso. "Hay muchas moradas en la casa de mi Padre", dice él mismo, y vosotros trabajáis para hacer esa casa mezquina y miserable, donde no hay espacio sino para los elegidos vuestros y no para los elegidos del Señor. 18

Cuando Montalvo se defiende de las acusaciones que se lanzan contra él porque dicen que está destruyendo la religión por medio de sus escritos, en su contestación no se justifica, sino que habla de la religión y de su grandeza, que nadie es capaz de destruir: 
La religión... es alta, serena, inviolable; por desmedido que sea el brazo de un malvado no la alcanza, porque ella está tan arriba como Dios. La religión nunca corre peligro ... Decir que los herejes van a quitar la religión es proferir una impiedad. La religión no está sujeta ni a la fuerza de los poderosos, ni a la astucia de los políticos, ni a los caprichos de los extravagantes. 19

Pero a la vez que expresa tan alto concepto de la religión, Montalvo se rebela contra el fanatismo estrecho que le acusa de hereje. Se queja de que no le es permitido apartarse ni un ápice de lo que se considera ortodoxo por los clérigos de su país. Para Montalvo las prácticas religiosas, por ejemplo, no constituyen la esencia de la religión :

E1, corazón puro es la única ofrenda que acepta el Señor. Las prácticas religiosas son convenientes y necesarias, pero distinguid, por Dios, la religión de la superstición, corred una línea entre la virtud y la hipocresía. 20

Esta hipocresia del clero, este formalismo hueco, repugnan a Montalvo:

Lo que si me propusiera con ardor sería establecer el cristianismo puro y limpio sobre las ruinas de la iniquidad, la hipocresía y el fanatismo...21

$Y$ los ataques al formalismo y cumplimiento de la forma por encima de las virtudes, son muy numerosos en las obras de Montalvo. Véase una muestra de estos ataques a la concepción de la religión como una forma de ritual y no como una idea:

¿Es por ventura concepto razonable pensar que con ir a gatas algunas leguas alcanzamos el reino de los cielos? Dios es altísimo, santísimo; hónrale con decoro, adórale con majestad ... Unirse al Infinito por la luz, sentirle en sús afectos propios, buscarle con las buenas obras, esto es ser santo. Pero somos de condición... que como un frailecico por ahí nos diga que labramos por el alma, sin sombrero nos vamos al infierno andando de rodillas. ${ }^{22}$

Debemos recordar que en las colonias de España, y también después del establecimiento de las repúblicas, toda la vida del país y la de cada individuo estaba regida por preceptos de indole con- 
fesional. La enseñanza en manos del clero, la imposibilidad de rebelarse por no-incurrir en las iras de la Inquisición, todo había contribuído a crear un ambiente de fórmulas religiosas que acompañaban todos los actos de la vida diaria de los sudamericanos. Montalvo mismo es un buen ejemplo de lo que sucedía al que se rebelaba contra la obediencia y observación del ritual, asi como de la profunda influencia del mismo. Pero aunque fué afectado por tan rígido ambiente, lo cual se nota en su estilo y en su lenguaje, así como en sus ideas fundamentales, Montalvo despreciaba y ridiculizaba estos formulismos, estos gestos vacíos que eran parte de la vida de su país:

Los de las escuelas religiosas del Ecuador, y todo descendiente de español... no proceden a ninguno de los actos nàturales, buenos o malos, sin abrumarse con una lluvia de ceremonias... Estornudan, y en seguida rezan un alabado... bostezan y se atracan la boca con los dedos, haciendo alli una barricada de cruces que no hay diablo que pase. Tosen, $y$ ofrecen una vela a Santa Rita... Se tropiezan y se acuerdan de las once mil vírgenes. Si les viene un zumbidillo a los oídos, ésas son las almas que piden oraciones y responsos; si se les hiela la punta de la nariz, el difunto don Mariano está penando. Mal año que ladre un perro a media noche, porque por ahí anda un muerto embozado de su mortaja, o va a morir una persona de familia, y si no le ponen por lo menos una vela por semana a su patrón, les da de palos...23

Protestando contra tal formalismo obligatorio, Montalvo expresa su deseo de que le dejen creer como él quiere, que le dejen ser creyente a su manera, que no confundan la esencia cristiana con el ritual. Siendo católico, aceptando básicamente los dogmas de la religión, dentro de su cristianismo quiere pensar a su manera, adorar según crea conveniente:

El cristiano sincero se elevará en éxtasis ante el cuerpo de Cristo oculto en las formas consagradas; el hombre hábil oirá misa con dignidad y humilde prosopopeya, sin ponersé en cruz ni besar el pavimento. 24

Déjenme rece o no rece, me santigüe o no me santigüe, que yo sé dónde y cómo le pido a Dios mis cosas... Yo me tiro de rodillas ante el Todopoderoso en presencia de una montaña cubierta de nieve eterna, o en alta mar, alzando los ojos a un cielo cargado de estrellas en mundo oscuro y silencioso. 25 


\section{Ideas de Montalvo sobre el clero}

En sus opiniones sobre el clero Montalvo distingue de una manera inequívoca entre él en general, su papel en la sociedad y el clero del Ecuador de su tiempo. En sus opiniones genéricas sobre el gremio podemos ver la razón de su desprecio por el clero de su país y de sus ataques contra los frailes que, según él, eran indignos del sacerdocio.

Habiendo sido atacado frecuentemente por los clérigos de su país, Montalvo muchas veces tuvo que expresar su opinión sobre ellos y su papel en la organización de un país. También mencionó muchas veces cuáles son los atributos que hacen de un sacerdote un digno ministro de Dios, y por lo tanto merecedor del respeto de todos.

El clero es uno de los elementos ésenciales de la sociedad humana, y lo ha sido desde sus orígenes... Con la venida de Jesús los sacerdotes recibieron el poder de atar y desatar . . con las manos puras, ya se entiende; encargo tan elevado como el ministerio de la religión, exige sin duda la más acrisolada virtud. Dios se halla tras la inocencia, la caridad, la humanidad. Dios se halla tras la misericordia, la compasión, el perdón. Dios se halla tras las virtudes. Los que las enseñan y practican, ésos son sus representantes; y cuando éstos son sus ministros, tienen títulos redoblados a la veneración del mundo. 26

La clase ... más respetable es el clero... Los eclesiásticos nos instruyen en nuestros deberes para con Dios, nos educan para el mundo místico; siembran máximas de moral para que recojamos buenas obras, y viviendo en santa mansedumbre son, o deben ser, contrarresto bienhechor de ignorantes y malvados. 27

Esta veneración por el clero y exaltación de sus atributos y deberes explican la indignación de Montalvo frente a las injusticias y abusos de los frailes. Según su' sentir, las obras de la Iglesia no eran buenas sólo por el hecho de proceder de ella. Veía y criticaba las faltas en la organización eclesiástica y sus efectos sobre las poblaciones de los países donde los clérigos tenían influencia sobre la vida en general.

La Iglesia es santa e infalible... La Iglesia, tal como la instituyó el divino fundador, es con efecto esa madre tierna y 
amorosa que no quiere sino el bien de sus hijos; como la han puesto las revoluciones de los siglos y los abusos de los hombres, puede merecer algún reparo. 28

Montalvo creía que el clero era propio de toda nación civilizada, como una parte integral, importante, indispensable de la sociedad, unido con el Estado, trabajando para el bien del país:

La felicidad [de un país] no puede hallarse sino donde la Iglesia y el Estado perfeccionen su unión sin lastimar las prerrogativas de cada una, sin llevar adelante pretensiones ambiciosas que acarrean de continuo males y desgracias evitables con sólo un poco de moderación y justicia. ${ }^{29}$

Era tan sincera su creencia en la santidad y necesidad del clero, que violentamente atacaba a quienes aconsejaban la separación de la Iglesia y el Estado (véase El Regenerador, tomo Ir, p. 28), y a los que no lo consideraban como elemento necesario y bienhechor de la sociedad:

Oh, vosotros, progresistas, políticos que no acertais a edificar sino sobre ruinas, sed servidos y escuchad: si sois más ilustrados que el clero, ¿por qué no le comunicais vuestras luces?; si más ignorantes, ¿por qué tratais de prevalecer sobre él? Como clase tan principal, los eclesiásticos han de gozar de los miramientos que nunca les han negado las naciones cultas: envilecer al clero es envilecer a la nación; embrutecer al clero es embrutecer a la nación. $\mathbf{3 0}$

Pero al mismo tiempo que exige veneración para el clero y la aceptación de su lugar en la sociedad, Montalvo también exige que aquél cumpla con su deber:

Importa que el clero abrace y defienda junto con nosotros los intereses comunes; que abrigue $y$ enseñe, practique $y$ propague las virtudes, que sea apoyo del gobierno, gloria de la patria. ${ }^{31}$

$\mathrm{Y}$ muchas veces expresa nuestro autor la convicción de que la ínica manera de llegar a un arreglo beneficioso para todos es establecer la ley del Patronato. Su opinión sobre este punto se resume como sigue: 
La ley del Patronato, sin el nefando artículo del fuero, éste es mi programa. República democrática donde reina el fuero eclesiástico, decid, señores, ¿se puede oír absurdo de marca mayor? 32

Debemos recordar que cuando Montalvo escribió su Mercurial Eclesiástica precisamente esa oposición al Patronato era lo que más importaba al clero. Este quería independencia del gobierno civil, conservando los fueros que le ponían fuera de la jurisdicción de los tribunales del país. Naturalmente, las opiniones de Montalvo acerca del Patronato provocaron la ira de los clérigos. Pero, como ya hemos visto, Montalvo nunca se expresó contra la clase sacerdotal en general; sus ataques eran contra los abusos de la Iglesia, como en el caso de sus artículos contra el poder temporal del Papado (véase El Cosmopolita, tomo I, pp. 263, 264, 265), contra los vicios de los miembros del gremio, contra la desmedida ambición política, contra los clérigos que

No son pastores que reúnen la grey y la consolidan en santo grupo; son lobos que acometen, ahuyentan y dispersan; ¿a qué hora ha de poder uno ser católico con semejantes guardianes del catolicismo? $\mathbf{3 3}$

Montalvo no se cansa de señalar en sus producciones cuáles eran las cualidades del clero de su país que lo hacían indigno de desempeñar su alto ministerio. Así, él acusa a sus miembros de traficar con la ignorancia y de corromper las costumbres, contrastando esto con su ideal de clérigo: el cura de Santa Engracia:

El cura de Santa Engracia no es adúltero ni violador... es hombre bueno, ciudadano virtuoso, sacerdote caritativo y cumple con sus deberes de miembro de la asociación general, de hijo y de párroco, sin desentenderse jamás de la ley de Dios ni de las obras de misericordia. Los clérigos prohiben estas cosas en mi país y hacen tráfico activo del Examinatorio de Padre Mazo... Las que leen esas negras páginas nada tendrán que aprender en Sodoma... Con esos despertadores, provocadores, corruptores de la mujer, es imposible que la conciencia quede ilesa, que la moral no sufra venenosas desportilladuras. 34

De esta manera, estableciendo la diferencia entre el sacerdote tal como debe ser y el sacerdote tal como es, Montalvo se niega a 
aceptar las prédicas y los consejos del cura ignorante, y no se considera con la obligación de respetarlo y venerarlo:

Los jóvenes, los intéligentes, los que sienten correr por las venas la sangre del siglo décimonono; éstos si le oyen no le creen al cura animal sin inteligencia ni conciencia. ${ }^{35}$

La explotación del pueblo por los curas también es uno de los temas de Montalvo. Ejemplos de estos casos de avaricia son numerosísimos en su obra, y en la cita que sigue resume nuestro autor las ideas que, según él, tenían los sacerdotes de los deberes de los feligreses:

El que algo da a la iglesia se condena poco, y mientras más da un buen cristiano, se condena menos - dijo el cura. El que da en abundancia se condena sino escasamente, y el que da cuanto posee ${ }_{\text {. nada se }}$ condena. ${ }^{36}$

También condena a los curas que realzan el uso de las imágenes, procesiones, fiestas, dando a todo esto más valor que a las obras buenas. Aquí se siente él ofendido en su sentido estético, así como en stu creencia de católico, diciendo que "là idolatría de los gentiles nunca tomó formas así, tan groseras y ridículas como la idolatría de nuestros tiempos". ${ }^{37}$ La ira del autor y st desprecio no van dirigidos a las imágenes en sí, ya que muchas veces se expresa de una manera respetuosa al hablar de aquéllas y de los Sacramentos; pero le molesta el uso inmoderado, el cambio de la idea por la imagen que ni siquiera es una obra de arte:

$\mathrm{Si}$ los clérigos hicieran de las Sagradas Imágenes un uso parco, razonable, aun se les pudiera tolerar; pero ese tráfico inmoderado, indecente, no es posible que nos cause respeto, por ciegos, tontos y fanáticos que seamos, como no seamos también pícaros que nos perdemos de vista. ${ }^{38}$

La hipocresia de los sacerdotes es otro punto que Montalvo trata de poner al descubierto. Como ejemplo baste citar su descripción del ayuno como la "ganga de los clérigos", que se extiende por páginas y más páginas. (Mercurial Eclesiástica, p. 39 y sigs.)

Como es natural, las descripciones que hace de las características personales de los miembros de este clero corrompido son siem- 
pre vitriólicas, rayando en groseras. Como ejemplo típico, he aquí una cita:

Eran los que venían tres sacerdotes de reposado y grave aspecto, uno de los cuales traía por delante una barriga veneranda asentada en el arzón... la cara abultada, sanguínea, los ojos comidos, las cejas blancas, los labios morados, el cuello corto, los hombros anchos, las piernas diminutas. $\mathbf{3 9}$

Descripciones semejantes se encuentran diseminadas por toda. la obra de Montalvo, siempre de acuerdo con esa vena satírica o abiertamente hostil.

$\mathrm{Su}$ actitud hacia el clero puede condensarse en sus propias palabras, cuando confiesa que es enemigo del clero "corrompido, ignorante y perjudicial" y amigo del "ilustrado, piadoso y útil". ${ }^{40} \mathrm{Y}$ el mejor resumen de tal actitud se halla en la página 150 de Mercurial Eclesiástica, donde, reconociendo el valor del gremio en general, lanza una palabrota en el rostro al clero del Ecuador.

\section{La moral cristiana y la moral católica}

Se puede decir que las diferencias entre el concepto de la moral cristiana en general y el de la moral católica tal como se comprenden ahora, no están en la esencia de la ética, sino en el énfasis que se da a ciertos aspectos de la observancia del ritual, que se había vuelto más importante que el mismo fondo o la idea básica de la ética llamada cristiana.

La moral cristiana es la inculcada por Jesús e ilustrada por su ejemplo. Es la moral implícita en la enseñanza del cristianismo y es la que históricamente tuvo sus raíces en la religión cristiana, que fué aceptada por la Iglesia y que dió su carácter distintivo a la civilización de ese orden. ${ }^{41}$ La extensión y el carácter de ella originalmente fueron determinados por estos tres factores: la tradición del judaísmo, las enseñanzas de Jesús y el mundo greco-romano. ${ }^{42}$

El paganismo y la licencia moral eran sinónimos en las mentes de los cristianos primitivos, como lo eran en las mentes de los hebreos contemporáneos de Jesús, porque la religión politeísta no tenía la fuerza moral para refrenar los instintos de los paganos, a pesar de que los códigos morales fueron presentados por muchos filósofos anteriores al cristianismo. La ética cristiana, por lo tanto, es conscien- 
te de Dios, y la moralidad no sólo era conducta externa sino motivación interior.

Aquí se encuentra el punto más importante de discrepancia entre lo que pudiéramos llamar moral cristiana y la moral católica. Esta última se basa en la interpretación del Evangelio, en el predominio de la tradición sobre las Sagradas Escrituras, ${ }^{43}$ en obediencia ciega a las autoridades superiores, y en la consciencia de que el ritual tiene tanta importancia como la motivación interior.

Ya hemos visto que a Montalvo le molestaba tal insistencia sobre el ritual. La reacción de los religiosos a esta actitud se hallaba dentro de lo normal, ya que la iglesia establecida, cualquiera que sea, siempre resiente que se critiquen sus rituales y que se les considere innecesarios. "Lo que provocaba la ira en la religión institucional (durante la vida de Jesús), al igual que la provoca ahora, era que se les dijera (a los sacerdotes) que la esencia consiste no en el ritual o corrección del credo, sino en el carácter ético interior, el cual no siempre correspondía al ritual." 44

Es indiscutible que el ecuatoriano opinaba que "todas las demandas del ritual y de la ley no son más que símbolos de la demanda real que se hace sobre el hombre moral para alcanzar pureza interior del pensamiento". ${ }^{45}$

Montalvo, además, siempre atacaba a los ultramontanos, definidos como personas que "consideran que el Papa es la autoridad suprema, infalible y por consecuencia única de todo lo que concieme a la religión, iglesia, moral y cada una de sus opiniones sobre estos asuntos demanda obediencia incondicional, interna así como externa". ${ }^{46}$

¿Cuál era la moral de Montalvo? ¿La moral cristiana, donde el énfasis predominaba sobre el pensamiento interior, o la moral católica oficial, donde el pensamiento individual se halla subordinado a la tradición y a la autoridad? Veamos cuáles eran sus preceptos en esta materia, para poder llegar a una conclusión.

\section{La ética de Montalvo}

Para Montalvo, Dios es la virtud y la práctica de las virtudes es amor a Dios. Y toda su obra se halla dedicada a la prédica de la virtud. Para él, en todo tiene que estar la virtud, en la vida diaria 
de cada individuo, en el gobierno, en la política; la virtud es el móvil $\mathrm{y}$ el fin de todas las buenas acciones del hombre, es amor a Dios, base de leyes, atributo principal de todo hombre de bien. Pero al ensalzar constantemente las virtudes Montalvo se queja siempre porque el mundo condena a los que son virtuosos, diciendo: "iOh, virtud!, eres sentencia de muerte." 47

Tal conocimiento de que las virtudes no producen más que dolor en este mundo, no impide que Montalvo siempre las predique. Aparece aqui su estoicismo, ya que él no se resigna humildemente al dolor. Para él, el sufrimiento causađo por la práctica de las virtudes le acerca a Dios y le muestra que tiene la fuerza y el valor necesarios. para padecerlo todo por lo que considera justo. Siempre hace el papel de mártir, pero no de mártir humilde: es una víctima orgullosa, que desprecia a sus enemigos y se considera en la obligación de honrar a Dios - a cuya semejanza fué creado- con st1 actitud estoica. En sus prédicas en pro de la humildad, sus palabras parecen. tomadas de cualquier sermón:

...honrar a Dios, trabajar, padecer con paciencia, virtudes son; sufrid las adversidades; trabajad, honrad a Dios, y no aspiréis a preeminencias vanas, ni os dejéis inficionar por el orgullo. 48

Pero debemos recordar que Montalvo establecía una diferencia muy marcada entre el orgullo que es pecado y el orgullo que es. dignidad:

El orgullo puro y limpio no se opone a la modestia, no hace sino defendernos contra la humildad, que, si no es la cristiana, se llama bajeza. El orgullo es un cierto conocimiento de la importancia propia, es deseo de corresponder a la naturaleza o al Criador, con un porte digno de sus favores. Traspasados ciertos términos, el orgullo es soberbia; mantenido en cierto grado, es una prenda del corazón y el espíritu. 49

Desafortunadamente, no nos da una definición de la humildad cristiana. Pero sí menciona en numerosas ocasiones el pundonor, la. dignidad del hombre como prendas morales que lo elevan. Este concepto de propia estima es de enorme importancia para nuestro autor:

... y aun cuando nuestros padres salieron desterrados del paraíso... salieron con toda la majestad con que Dios les ha bía engrandecido... 
... Maldecido o perdonado, inocente o criminal, impoluto o con mancilla, el hombre siempre es la obra de Dios, hecho a su semejanza, y como tal digno de respeto. 50

Según lo hemos visto en la sección dedicada a las creencias religiosas de Montalvo, la humildad cristiana se debe a Dios y no a otros hombres, por elevada que sea su jerarquía civil o eclesiástica. Sin embargo, las prédicas del autor dirigidas a sus lectores no difieren mucho de las de la aceptada moral católica. Predica el trabajo, ya que considera que es virtud, y en el trabajo está la salvación del hombre:

El laboreo de la tierra, el trabajo de las propias manos, es la única fuente de riquezas verdadera y permanente. 51

Es más, su opinión acerca de los problemas de índole social, que en sus tiempos empezaban a cobrar importancia, era que representaban frutos de ocio y, por lo tanto, indignos del hombre virtuoso:

E1 comunismo y el socialismo, estos azotes de las modernas sociedades, no han salido, no podían salir de un pueblo en donde cada ciudadano se contentaba con una porción de tierra que él labraba con sus manos. 52

Nótese la expresión "se contentaba", ya que en muchos otros pasajes predica la continencia, y dice que no hay" que aspirar a alcanzar estados imposibles, sino conquistar la ambición, la soberbia.

Aboga siempre por la misericordia y el perdón, ya que "las obras de misericordia son préstamos que hacemos al Señor". ${ }^{53} \mathrm{La}$ misma palabra "préstamos" trae consigo la idea de recompensa, si no ya en este mundo, sí en el otro. Pero para Montalvo la caridad no tiene que ser parte del ritual, no debe ser considerada como obligación.

Sin buena voluntad no hay caridad; los que dan por fuerza

labran para el demonio; los que por orgullo, están condenados. $5 \dot{4}$

La recompensa divina, para él, está en el mismo hecho de la caridad o el perdón.

Predica la sabiduría y la cordura que son necesarias para obrar en bien del prójimo:

Sed sabios, si es posible; pero antes de serlo, procurad ser cuerdos. No persigais, no difameis, no calumnieis... 55 
Pero aquí también surge la idea de la recompensa; ya intima, personal, ya divina, de la cual no duda el autor por un momento cuando dice:

En profesando el sufrimiento y la cordura, el Señor os tendrá presente. . 56

Estos preceptos morales ortodoxamente católicos resaltan en sus amonestaciones y recomendaciones sobre la riqueza y la pobreza, donde Montalvo siempre aconseja resignación, ya que la riqueza viene de Dios; predica humildad, refrenamiento de la cólera, respeto a la. naturaleza por ser obra de Dios.

Al hablar de la mujer, tampoco se desvía el ecuatoriano de los puntos de vista de la Iglesia. Hay que notar que todas sus descripciones de mujeres tienen cierto elemento de voluptuosidad, que por cierto no cuadra muy bien con su austeridad literaria ni con sus prédicas moralistas. Como dice Efrén Reyes en la biografía de Montalvo, éste evidentemente nunca pudo dominarse en este sentido y toleraba su inclinación amorosa hacia toda mujer bonita, casi a su pesar. Sin embargo, recomendaba a los demás que respetaran a la mujer y se preocupaba por la condición que ésta guardaba en su país, ya que la consideraba ignorante y embrutecida. Aconseja la educación de la mujer, pero el sistema que recomienda no podría provocar la ira de ningún clérigo:

\begin{abstract}
... Los hombres mismos somos aquí muy bastos e ignorantes; poco tenemos que enseñarles; pero si tenemos poco, aprendamos y compartamos con ellas las 1uces adquiridas. No hablo de las ciencias; lo abstruso nada les importa; más aún, casi siempre las adorna en su perjuicio. Hablo de este arte sublime por el cual la mujer sabe ser hija desde luego, esposa en seguida y después madre. En esta triple y tierna faena se envuelve todo to que ella debe aprender y saber. 57
\end{abstract}

No, no queremos medias azules; queremos mujeres instruídas en la virtud, apreciadoras de la honra, dignas de nuestro respeto, sin quitarles la instrucción necesaria para su encargo y para la cultura y adorno de inteligencia que alcanzan nuestros tiempos. 58

En resumen, considera que la mujer que es buena hija, buena esposa y buena madre posee todas las virtudes cristianas y es digna 
compañera de su esposo dejándose guiar por él. Nos dice que las ciencias son para los hombres $y$, sin embargo, habla vagamente de ciertos adornos de cultura que cuadren con su condición de esposa y madre. Nada más ortodoxo que tales puntos de vista acerca de la educación de la mujer y su posición en la sociedad.

Incansablemente predica las buenas costumbres, la conducta moral en todo: política, vida diaria, producción artística. "Buenas costumbres. Sin ellas el respeto de los demás es imposible...." 59 Aquí surge el eterno "qué dirán" y además de la recompensa intema está el miedo a la opinión del mundo. Por tal razón, la vergüenza es una gran virtud para Montalvo.

Su lección moral se halla contenida en esta corta frase:

Todo el que entra en su casa por la tarde sin haber hecho algún bien a sus semejantes, ha perdido el día. 60

Sus opiniones acerca de la literatura y el arte quedan analizadas en "El panorama cultural de Montalvo", por Roberto Agramonte (Repertorio Montalvino, Ambato, 1935), donde el autor nos da un cuadro completo de los alcances culturales de aquél y de las influencias que con más fuerza obraron sobre su formación intelectual. Pero las ideas de Montalvo sobre el valor de una producción literaria son ortodoxamente católicas : él condena toda obra que no encierre una lección moral. El escritor, para ser bueno, tenía que moralizar o predicar :

... Escritor cuyo fin no sea el provecho para sus semejantes les hará un bien con tirar su pluma al fuego; provecho moral, universal ...61

\section{Conclusión}

En la masa de contradicciones presentes en la obra de Montalvo podemos establecer algunos puntos fijos en los cuales siempre mostró su parecer de la misma manera, ya hablara de la religión, del clero o de la moral.

En la religión.-Montalvo era cristiano, católico, pero no ultramontano. Su creencia en Dios era sincera, su respeto por la religión genuino. Atacó a los ritualistas, a los que ponían la tradición por en- 
cima de la misma religión, a los que habían convertido el culto en la esencia de esta última. En las cuestiones de dogma no hubo diferencia entre su criterio y el de la Iglesia. Pero en los puntos de interpretación del dogma, en cuestiones de FORMA, Montalvo mostró libertad de opinión.

Era enemigo de la intolerancia religiosa, pero sólo cuando se atacaban sus propias ideas, y así se muestra intransigente al hablar del panteísmo, del socialismo, del comunismo, del ateísmo... Se revela profundamente intolerante ante toda doctrina que él no comparte y que choca con sus conceptos de la vida y de la virtud. Su lenguaje al hablar de estos "impíos" está lleno de violencia bíblica y su amenaza es la misma que la del cura: la ira de Dios que será desatada contra los que lo niegan, el castigo en el otro mundo para quienes dudan de la inmortalidad del alma. En otras palabras, Montalvo amedrentaba con las amenazas de la Iglesia a los que no creían en lo que él sí creía.

En la actitud hacia el clero.-Montalvo considera al clero no sólo necesario, sino esencial para el desarrollo normal de un país. El sacerdote tenía que ser el modelo de virtud, ya que el hombre de sotana tenía para él más prestigio que el hombre de levita. De ahí proviene su odio hacia el clero que rebajaba el alto concepto de la clase en general por su ignorancia, superstición, avaricia y sed de poder. Para Montalvo el sacerdote tenía que ser un santo, un hombre superior a todos los apetitos humanos, ya que era ministro de Dios. Sus ataques violentos y hasta groseros contra los curas del Ecuador se basan en el hecho de que éstos, que según Montalvo debían ser modelos para los demás, no eran sino hombres, y hombres débiles, indignos por lo tanto de desempeñar su alto ministerio.

En resumen, podemos decir que nuestro autor tenía tan alta opinión del clero y del ministerio divino, que las debilidades humanas de los ministros de Dios provocaban su ira y le llevaban a desafiar su autoridad porque moralmente los consideraba inferiores a sí mismo.

En la moral.-La prédica moral de Montalvo no difiere mucho de la moral católica, sino en los puntos de énfasis y en los de valores intrínsecos, y aun en éstos su concepto no aparece muy claro ni bien definido. 
En la Iglesia católica el castigo, la recompensa, el sistema de penitencia, la forma y el ritual son de gran importancia. Para Montalvo la virtud, la práctica de las buenas costumbres traen sus propias recompensas en ellas mismas. Pero reconoce que la virtud acarrea consigo la recompensa y la falta de virtud el castigo divino; en. numerosos pasajes advierte que el hombre es malo y necesita de una rienda que sujete sus pasiones. (Por ejemplo, véase El Cosmopolita, tomo II, p. 309.) Pero al mismo tiempo establece la diferencia entre el hombre digno, que no necesita de la rienda del temor para ser persona moral, y el que sólo es bueno porque teme. Sin embargo, nunca niega que la base de la moral y la virtud se halla en la religión, aunque se contradice en este punto al hablar de los filósofos y héroes de la era pre-cristiana. A pesar de tales contradicciones, es indudable que pará Montalvo la idea del bien es también la idea de Dios, unida a la religión, y esta definición de la moral coincide con là que da la Enciclopedia Católica:

Morality may be defined as human conduct insofar as it is fully subordinated to the ideal of what is right and fitting. The telation of morality to religion has been subject to debate: it is maintained that high moral action is altogether independent of religion. The Church has ever afirmed that the two are essentially connected and that apatt from teligion the observance of motal law is impossible.

The Chutch admits that moral law is knowable to reason... but if moral is divorced from religion... much will be wanting. The man will be destitute of the strong motives for obedience and the knowledge of tremendous sanctions attached to its neglect - motives which experience has proved to be necessaty as a safeguard against the influence of the passions. 62

En las amonestaciones de Montalvo no hay nada que pueda molestar a la Iglesia. Recomienda humildad, sumisión a las autoridades civiles, respeto al clero, práctica de las virtudes, humildad cristiana... En sus puntos de vista literarios, por poco recomienda que se quemen los libros de Rabelais y los de Proudhon, los unos por inmorales y los otros por herejes.

Mas al establecer las anteriores semejanzas entre la moral católica y la prédica de Montalvo debemos recordar que éste reconocía que los conceptos fundamentales de la moral no habían cambiado 
desde los tiempos de la antigüedad, y que si hubo discrepancia entre las ideas del ecuatoriano y las de la Iglesia fué a causa de los cambios sufridos por ésta al paso de los siglos y bajo la presión de las circunstancias.

Podemos decir, pues, que la moral de Montalvo era exteriormente católica, pero fundamentalmente sin el apego al ritual, con énfasis sobre la recompensa interna, y que las diferencias entre los preceptós de la Iglesia y los conceptos morales de Montalvo, si existían, eran de FORMA y no de FONDO.

$$
\text { * * * }
$$

Analicemos brevemente las razones por las cuales un hombre que tuvo el valor de levantarse contra los curas de su país y sufrir persecuciones por sus escritos no tuvo el valor de tener ideas originales, por qué todas sus ideas podrían haber sido sacadas de un sermón y por qué hasta su mismo lenguaje era de cátedra sagrada.

En primer lugar debemos recordar el ambiente tan vívidamente pintado por él mismo. Predominaba la influencia de la Iglesia, ya fuera en forma de ritual, de ideas o de superstición; era una osadía rebelarse contra las formas, pero la idea de dudar de la esencia resultaba inconcebible en un ecuatoriano de la época de Montalvo.

Aunque acusa a sus compatriotas de relacionar todo acto de la vida diaria con el ritual, esto era inevitable en países donde la Iglesia tenía el control de la vida pública y privada de los individuos a través de la confesión y donde la Inquisición reinó durante tantos años. Así, condenando tal alianza estrecha de la vida diaria y el ritual religioso, Montalvo mismo no había podido escaparse de la influencia. En sus metáforas, en su lenguaje, hablando de cualquier cosa, muestra inmediatamente cuál fué su cultura básica y de dónde provenían los símbolos que con más facilidad acudían a su mente.

Las contradicciones que se encuentran en Montalvo se deben a dicha influencia de siglos en el carácter de su país. La libertad que predicaba y que él llamaba libertad de pensamiento, no era sino libertad de forma, no verdadera emancipación de ideas. Las acusaciones que lanzaba contra el clero, asumían un tono no mesurado. Hasta esta importancia que Montalvo concede a la forma, a las buenas costumbres, al "qué dirán", sus amonestaciones de evitar escándalo, son 
reflejos de la moral católica formalista y ritualista que reinó en su país por siglos y de cuyo influjo le era imposible escapar.

Montalvo se consideraba reformador, pero en su caso la transformación era la vuelta al cristianismo primitivo, sin énfasis en el ritual de la Iglesia que ésta empleaba en provecho propio. Su grande originalidad resalta en esta rebelión contra el ritual que era parte de él mismo. Sus exhortaciones morales sí son prédicas de la moral católica, pero él muestra haber comprendido que ésta no es sino la moral universal establecida y conocida antes del cristianismo, adoptada por la Iglesia, revestida de ritual y finalmente subordinada a éste.

En numerosos pasajes de su obra adviértese esta comprensión de que la moral que él predica no es nacida de la Iglesia sino de la ley moral universal, del pensamiento humano anterior al cristianismo. Sin embargo, por su educación, por la influencia religiosa de siglos del español, él no había podido separar la religión de la moral; la decencia, de la idea del castigo y recompensa divinos.

Por esta razón podemos decir que la moral de Montalvo es moral cristiana más que católica, y en esta independencia del ritual nuestro autor miuestra que había roto en parte las cadenas impuestas al pensamiento por la Iglesia y vislumbrado - siempre dentro de su concepto religioso- las ideas FUNDAMENTALES de la moral católica, que son las de la moral universal.

\author{
Sarah Nemtzow, \\ University of California \\ at Los Angeles.
}

\title{
NOTAS
}

1 Juan Montalvo, El Regenerador, tomo II, p. 187. Garnier Hnos., París, s. f.

2 Juan Montalvo, El Cosmopolita, tomo II, p. 208. Garnier Hnos., París, s. f.

3 Juan Montalvo, El Regenerador, tomo II, p. 163.

4 Juan Montalvo, Mercurial Eclesiástica, p. 111. Biblioteca de Europa y América, París, 1884.

5 Juan y Ulloa, Noticias secretas de América, tomo II, p. 169. Ed. Ámérica, Madrid, 1918.

6. Ibid., ibid., p. 172. 
7 Ryan, Edwin, DD., The Chutch in the South Ametican Republics, p. 24. Nueva York, 1932.

8 Noticias sectetas de América, tomo II, p. 196.

9 El Cosmopolita, tomo I, p. 367.

10 Ibid., ibid., p. 369.

11 El Cosmopolita, tomo I, p. 370.

12 Ibid., ibid., p. 255.

13 Ibid., ibid., p. 150.

14 El Regenetador, tomo II, pp, 140-141.

15 Ibid., ibid., p. 142.

16 El Cosmopolita, tomo I, p. 216.

17 Ibid., ibid., p. 130.

18 Ibid., tomo II, p. 134.

19 El Regenerador, tomo II, p. 62.

20 El Cosmopolita, tomo I, p. 218.

21 Ibid., ibid., p. 179.

22 Juan Montalvo, Capítulos que se le olvidaron a Cervantes, tomo I, p. 29. Garnier Hnos., París, 1930.

23. El Cosmopolita, tomo I, pp. 217-218.

24 El Regenerador, tomo II, p. 211.

25 Mercurial Eclesiástica, pp. 22-23.

26 El Regenetadot, tomo II, pp, 24-25.

27 Ibid., ibid., p. 26.

28 El Cosmopolita, tomo I, pp. 262-263.

29 Ibid., ibid., p. 262.

30. El Regenerador, tomo II, p. 24.

31 Ibid., ibid., p. 34.

32 Metcutial Eclesiástica, p. 109.

33 Ibid., p. 21.

34 Ibid, pp. 99-100.

35 Ibid., p. 113.

36 Capítulos que se le olvidaron a Cervantes, tomo I, p. 58.

37 Mercurial Ectesiástica, p. 150.

38 Ibid., p. 145.

39 Capitulos que se le olvidaron a Cervantes, tomo I, p. 118.

40 Mercurial Eclesiástica, p. 110.

41 Henson, H. H. (Bishop of Dutham), Christian Morality, p. 32. Oxford, 1936.

42 Ibid., p. 137.

43 Ibid., p. 96.

44 Hall, T. C., DD., History of Ethics within Organized Christianity, p. 58. Nueva York, 1910.

45 Ibid., p. 61.

46 Encyclopaedia Britannica, vol. 27, p. 571.

47 Buscapié, p. 14. 
48 Capítulos que se le olvidaron a Cervantes, tomo I, p. 326.

49 Prólogo a Capitulos... (Buscapié), p. 61.

50 El Cosmopolita, tomo II, pp. 238-239.

51 Ibid., tomo I, p. 54.

52 Ibid., ibid., p. 149.

53 Capitulos que se le olvidaton a Cetvantes, tomo I, p. 121.

54 Ibid., ibid., p. 122.

55 Mercurial Eclesiástica, p. 17.

56 El Cosmopolita, tomo I, p. 325.

57 Ibid., ibid., p. 21.

58 Ibid., ibid., p. 24.

59 El Regenetadot, tomo I1, pp. 224-225.

60 El Cosmopolita, tomo II, p. 342.

61 Prólogo a Capitulos que se le olvidaron a Cervantes (Buscapié). p. 11 .

62 Catholic Encyclopaedia, tomo X, p. 559. 
